一般手術における輸血削減への取り組み一周術期のPatient Blood Management を考える— Patient Blood Management (PBM)の概念

山浦 健*

[要旨］輸血の安全性は高まったにもかかわらず, 免疫反応や輸血関連循環過負荷などの重篤な輸 血関連合併症の問題は残っている他, 予後にも影響を与える. Patient Blood Management (PBM)は，同種血輸血を可能な限り回避するためのプログラムである. PBMでは術前は貧血，鉄 欠乏や抗血栓療法の有無を評価し, 貧血の補正と止血凝固能を最適化する. 術中は手術時期の決定, 術式の選択や麻酔管理方法, 自己血回収装置などを通して出血量と輸血量の軽減に努める. 術後は 体温管理も含めて出血量の軽減に努め, 出血量のモニタリングを行い, 必要に応じた酸素投与や適 正な薬物介入を行う. 同種血輸血を行う場合でも evidenceに基づいた輸血製剤の選択，および最 小限の投与量を心がけることが重要となる.

キーワード : 輸血, 同種血輸血, 貧血, 予後, 手術

\section{はじめに}

Patient Blood Management(PBM) とは同種血輸 血の使用を可能な限り回避する輸血療法の一つであ り，2010年頃に登場した概念である ${ }^{11}$.

\section{I 輸血副作用}

肝炎ウイルスを含めた輸血関連感染症は検査法の 進歩などにより激減し, 同種血輸血の安全性は高ま つたにもかかわらず，免疫反応や輸血関連循環過負 荷 (transfusion-associated circulatory overload : TACO) などの重篤な輸血関連合併症の問題は残っ ている. 日本赤十字社の報告 ${ }^{2}$ によると, 副作用の うち感染症(疑いを含む)の割合は 4〜 5\%で, GVHD (移植片対宿主病) は放射線照射が開始されてからは ほとんど報告されていない。また，血液型不適合輸

*九州大学大学院医学研究院麻酔 $\cdot$ 蘇生学分野
血を含めた溶血性副作用も医療安全上は問題となる が，報告例はごくわずかであり，副作用報告のほと んどが非溶血性副作用である。輸血副作用の多くは 蕁麻疹，アナフィラキシー(ショックを含む)，血圧 低下，呼吸困難，発熱反応であり，その他非溶血性 副作用としては輸血関連急性肺障害(transfusionrelated acute lung injury : TRALI), TACO ども ある。

輸血製剂の中では，赤血球濃厚液と血小板濃厚液 によるものが多いが，使用量から考えると血小板濃 厚液によるものの頻度が高く，新鮮凍結血漿も多く 見られる。副作用の内訳としては，発熱反応，蕁麻 疹, 呼吸困難の割合が高いのに対して，血小板濃厚 液と新鮮凍結血漿では菉麻疹とともに，アナフィラ キシー(ショックを含む)の割合が非常に高い.

特に最近注目されているのがTRALI, TACOで

著者連絡先 山浦 健

T 812-8582 福岡県福岡市東区馬出3-1-1

九州大学大学院医学研究院麻酔・蘇生学分野 
あるが，TRALIは輸血用血液製剤中の白血球抗体 (HLA 抗体, HNA 抗体) が受血者の白血球もしくは 血管内皮細胞などと反応し, 肺の毛細血管内皮細胞 の透過性元進が起こることが原因と推定されてい る。このため輸血用血液製剤に含まれる白血球を除 去すること，400mLの血液製剤のほぼ100\%が男性 献血者から採血された血液から製造することになっ たこと(抗白血球抗体は妊娠等により産生されるこ とが多いため)により激減している。一方，最近高 齢化に伴い増加しているのがTACOであり, 輸血 後 6 時間以内に起こることが多い呼吸不全を伴う心 不全である。TACOのリスク因子としては心機能 障害，特に拡張能障害，高齢者，腎機能障害，低ア ルブミン血症などである ${ }^{3)}$.

\section{II 貧血・輸血と予後}

術前貧血は心臟血管手術および非心臓手術では独 立した予後予測因子であり, 術後 30 日死亡率はへ マトクリットが正常から 1\%下がるごとに $1.6 \%$ 増加 する ${ }^{4)}$ (6) た, 術前からの貧血に対する介入も重要 となる。

一方，輸血量が多くなるに従い，全身感染症のリ スクは上昇し ${ }^{7)}$, 合併症および死亡率も上昇する ${ }^{8)}$. 予後を考えたとき, 可能な限り同種血輸血は避ける ことが望ましく, PBMにより, 同種血輸血を可能 な限り回避する。

\section{III 手術とPBM}

PBMが主に用いられるのは手術であり, 術前か ら介入し, 術中, 術後の周術期管理を通して同種血 輸血を回避する計画医療である。特に術前からのア プローチが重要視され，貧血と鉄欠乏を評価し介入 することが重要である。また，抗血栓療法の有無や 併存疾患についても把握し, 止血凝固能も最適化し ておく。また，それぞれの患者にとって適切な輸血 回避プログラムを決めておくことも重要となる。貧 血の補正計画，自己血貯血時期を含めた適正な手術
時期の決定，術中の出血量を減らすための術式の選 択や麻酔管理方法，自己血回収装置の使用などを通 して出血量の軽減および同種血輸血を避ける計画を 立てておく．また，同種血輸血を行う場合でも evidenceに基づいた輸血製剤の選択，および最小限の 投与量を心がけることも重要となる。

術後は体温管理も含めて出血量の軽減に努め, 出 血量のモニタリングや管理を行い，必要に応じた酸 素投与や適正な薬剤使用などの計画を立てておくこ とも重要となる。

\section{PBMの3本柱}

このような周術期のPBM を 3 本柱で考え, 術前, 術中, 術後のそれぞれの時期に (1) 赤血球の最適化, (2) 血液の喪失を最小限にすること, (3) 貧血時の管 理を計画することが提唱されている ${ }^{9)}$. ポイントと しては，術前のへモグロビン量を増加させ，止血凝 固能を最適化すること, 手術手技や機器の改善, 麻 酔管理の工夫により術中・術後の出血量を減少させ ること，エビデンスに基づいた限定的・制限的な血 液製剤の使用をすることである。

術前の 3 本柱では, (1)術前の貧血と鉄欠乏を評価 し，鉄剤や葉酸などの投与により原因治療を行い， ヘモグロビンを最適化しておく.(2)抗血栓療法など も含女て出血リスクを特定し管理・治療を開始する. 不要な検査を避けることで採血に伴う血液の啔失量 を最小限にする，出血量を減らす計画およびそのリ ハーサルも重要となる。(3)術前にどの程度の貧血に 耐えられるのか，そのため，どの程度の心肺予備能 があるのかを評価しておく。

術中の 3 本柱では, (1)赤血球産生と赤血球容積の 最適化に合わせた手術時期の決定. (2)術中出血量を 最小限にするため，細心の手術手技や麻酔管理方法 による止血，自己血回收装置の利用，凝固障害を避 けるための患者体位や加温，抗線溶薬を含めた薬物 介入を考慮する. (3)貧血時の対処として，換気と酸 素化を含めた心肺機能の最適化を行い，輸血する場 
合でも制限的輸血を行う。

術後の 3 本柱では, (1) 貧血と鉄欠乏に対する管理 の他，使用薬剤と薬物相互作用にも注意をはらう。 (2) 出血量を最小限にするために, 術後出血に対す るモニ夕ーと管理, 患者の保温, 検査用採血を最低 限にし, 薬物相互作用や副作用に注意をはらう。ま た，消耗性の貧血を避けるために感染症の早期治療 にも注意をはらう。(3)術後貧血に対しては, 酸素供 給を最大限にし, 酸素消費量を最小限にする。感染 症の治療，および貧血を許容することも考慮する. 輸血する場合でも輸血制限療法を行うことが重要で ある。

その他, PBMを推進するための教育, プロトコ ールの作成, 貧血管理方法, 凝固障害に対する最適 化, 出血量を最小限にする対策, 患者中心の意思決 定による(輸血拒否を含めた)輸血，予後調査など体 系的に捉える取り組みが行われ，同種血輸血回避に 向けた取り組みがなされている ${ }^{10)}$.

\section{まとめ}

Patient Blood Managementの理論的根拠が, evidence に基づいた輸血療法の実践と同種血輸血の回 避に繋がる。特に手術における PBMでは術前の赤 血球量を増やし, 抗血栓薬の休薬も含女て止血凝固 能を最適化しておくこと, 術中は手術手技や機器の 改良，保温を含めた麻酔管理および術後のモニタリ ングにより術中・術後の出血量を最小限にし, 輸血 する場合でも evidenceに基づいた限定的・制限的
な血液製剤の使用が重要となる.

\section{参考文献}

1）紀野修一：Patient Blood Management(PBM) とは. 医 学のあゆみ $243: 273-278,2012$

2）輸血情報 1807-162 赤十字血液センターに報告された 非溶血性輸血副作用-2017年 - 〈http://www.jrc.or.jp/ $\mathrm{mr} / \mathrm{news} / \mathrm{pdf} /$ yuketsuj_1807_162.pdf $\rangle$ (2018.12.24閲覧)

3）日本赤十字社 血液事業本部 安全管理課：Haemovigilance by JRCS 2016. 2017 〈http://www.jrc.or.jp/mr/ relate/info/pdf/Haemovigilance2016_jp_f2.pdf $\rangle$ (2018.12.24閲覧)

4) Ranucci M, Di Dedda U, Castelvecchio S, et al. : Impact of preoperative anemia on outcome in adult cardiac surgery : a propensity-matched analysis. Ann Thorac Surg $94:$ 1134-1141, 2012

5) Gupta PK, Sundaram A, Mactaggart JN, et al. : Preoperative anemia is an independent predictor of postoperative mortality and adverse cardiac events in elderly patients undergoing elective vascular operations. Ann Surg $258: 1096-1102,2013$

6) Wu WC, Schifftner TL, Henderson WG, et al. : Preoperative hematocrit levels and postoperative outcomes in older patients undergoing noncardiac surgery. JAMA $297:$ 2481-2488, 2007

7) Horvath KA, Acker MA, Chang H, et al. : Blood transfusion and infection after cardiac surgery. Ann Thorac Surg 95 : 2194-2201, 2013

8) Ferraris VA, Davenport DL, Saha SP, et al. : Surgical outcomes and transfusion of minimal amounts of blood in the operating room. Arch Surg $147:$ 49-55, 2012

9) Spahn DR, Goodnough LT: Alternatives to blood transfusion. Lancet $381: 1855-1865,2013$

10) Meybohm P, Richards T, Isbister J, et al. : Patient blood management bundles to facilitate implementation. Transfus Med Rev 31 : 62-71, 2017 


\title{
Concept of Patient Blood Management
}

\author{
Ken YAMAURA
}

Department of Anesthesiology and Critical Care Medicine, Graduate School of Medical Sciences, Kyushu University

Blood transfusion has gradually become safer, though it is still associated with complications such as immune reactions and transfusion-associated circulatory overload and prognosis. The patient blood management (PBM) program allows avoidance of allogeneic blood transfusion as much as possible. In PBM, preoperative assessment of anemia, iron deficiency, and antithrombotic therapy are performed, followed by correction of anemia and coagulopathy. To minimize intraoperative blood loss, surgical strategy and anesthetic management should be considered beforehand. To reduce postoperative bleeding, it is important to maintain and monitor body temperature as well as oxygen levels and proper drug interventions, if necessary. Even if blood transfusion is inevitable, appropriate and minimum transfusion should be considered in such cases.

Key Words : Patient Blood Management, Blood transfusion, Anemia, Morbidity, Mortality

The Journal of Japan Society for Clinical Anesthesia Vol.39 No.5, 2019 